\title{
Observasi Parameter Meteo-Oseanografi Dalam Musim Peralihan I di Selat Lirang
}

\author{
Observation of Meteo-Oceanography Parameters on Transition Monsoon I in Lirang Strait
}

\author{
Mukti Trenggono $^{(1)}$ dan Teguh Agustiadi $^{(2)}$ \\ ${ }^{(1)}$ Program Studi Ilmu Kelautan, FPIK-Universitas Jenderal Soedirman \\ ${ }^{(2)}$ Balai Riset dan Observasi Laut. Jl. Baru Perancak, Negara, Jembrana, Bali \\ E-mail Korespondensi: mukti.trenggono@unsoed.ac.id
}

\begin{abstract}
Abstrak
Selat Lirang merupakan daerah strategis sebagi jalur pelayaran antar pulau di Maluku. Kegiatan pelayaran tersebut memerlukan pertimbangan pengaruh parameter meteo-oseanografi. Kurangnya informasi data di wilayah tersebut menjadi pertimbangan pentingnya penelitian ini dilakukan, dengan tujuan memberikan informasi kondisi meteo-oseanografi untuk kegiatan transportasi laut di wilayah Selat Lirang. Pengambilan data dilakukan dengan metode observasi terhadap parameter angin, gelombang, arus dan pasang surut pada tanggal 15-19 April 2016 untuk merepresentasikan data satu bulan yang termasuk dalam musim Peralihan I. Data hasil observasi dianalisis menggunakan metode kuantitatif. Analisis korelasi digunakan untuk melihat hubungan pembangkitan angin dan pasang surut terhadap arus. Berdasarkan hasil penelitian diketahui bahwa angin mempengaruhi gerak arus dengan frekuensi angin dominan berasal dari baratdaya, sebagian kecil berasal dari barat dan barat laut. Arus arah meridional dan zonal pada kedalaman $1.5 \mathrm{~m}$ dan $7.5 \mathrm{~m}$, pola arus total pengukuran lebih mendekati besarnya kecepatan arus residu. Perhitungan RMSE arus total dengan arus pasang surut di kedalaman $1.5 \mathrm{~m}$, arah meridional memiliki nilai 0.0184 dan zonal 0.0054 , sedangkan arus total dengan arus residu memiliki nilai 0.0086 untuk meridional dan nilai 0.0162 untuk zonal. Pada kedalaman $7.5 \mathrm{~m}$, arus total dengan arus pasang surut memiliki nilai 0.0204 arah meridional dan 0.0183 arah zonal, sementara arus total meridional terhadap arus residu memiliki nilai 0.0105 dan arah zonal 0.0071 . Kemiripan pola arus pada kedua kedalaman ini tidak jauh berbeda, yaitu arus pengukuran lebih mendekati pola arus residu yang dibangkitkan oleh angin. Hasil pengukuran gelombang menunjukan ketinggian gelombang relatif rendah, hal ini berhubungan dengan pembangkitan angin lokal yang lemah pada saat observasi dilakukan.
\end{abstract}

Kata kunci: Meteo-oseanografi, Musim peralihan I, Selat Lirang.

\begin{abstract}
Lirang Strait is a strategic area that becomes inter-island shipping lanes in Maluku. Shipping activity certainly can not be separated from the consideration of the influence of meteo-oseanografi factors. Lack of data information in Lirang Strait was important consideration for doing this research that aims to provide an information of meteo-oceanography conditions for marine transportation activities. Observation method was used to collected wind, wave, current and tidal data on 15-19 April 2016 to represent one month in Transition Monsoon I. Based on the research showed that the wind given an impact to the current movement was dominantly from the Southwest, and some of them were from west and northwest. Meridional and zonal at the depth of $1.5 \mathrm{~m}$ or $7.5 \mathrm{~m}$, the velocity of total current showed the closest value to the residual current. The RMSE calculation of total current with tidal current at a depth of $1.5 \mathrm{~m}$ has a value of 0.0184 for meridional and 0.0054 for zonal, while the total current with residual current has a value of 0.0086 (meridional) and 0.0162 (zonal). At a depth of $7.5 \mathrm{~m}$, the meridional total current with the tidal current has a value of 0.0204 and zonal has 0.0183 , then the total current with the residual current has a value of 0.0105 for meridional and 0.0071 for zonal. The similarity of the current pattern at these two depths was not much different, ie the total current was closer to the pattern of residual currents generated by the wind. While the wave measurement results showed relatively small wave conditions, this corresponds to weak local wind generation in the observation time.
\end{abstract}

Keywords: Meteo-oceanography, Transition monsoon I, Lirang Strait. 


\section{Pendahuluan}

Selat Lirang merupakan perairan sempit yang menghubungkan Pulau Lirang dan Pulau Wetar dimana kedua pulau ini merupakan bagian dari pulau terluar Indonesia yang berbatasan dengan Republik Demokratik Timor Leste (Keputusan Presiden RI no 6 tahun 2017). Perairan Selat Lirang menjadi daerah yang sangat strategis karena menjadi jalur transportasi laut antar pulau di Maluku. Perahu dan kapal yang akan melakukan aktifitas pengangkutan penumpang dan barang wilayah tersebut memiliki potensi ancaman bahaya berupa angin, gelombang laut dan arus. Sehingga diperlukan informasi terkait data tersebut agar aktivitas transportasi laut dapat berjalan dengan baik.

Menurut Peraturan Presiden Repulik Indonesia Nomor 33 Tahun 2015 mengenai Rencana Tata Ruang Kawasan Perbatasan Negara di Provinsi Maluku menyebutkan bahwa Pulau Lirang, Kecamatan Wetar Barat termasuk di dalamnya Selat Lirang masuk kedalam Kawasan Strategis Nasional yaitu wilayah yang penataan ruangnya diprioritaskan karena mempunyai pengaruh sangat penting secara nasional terhadap kedaulatan negara, pertahanan dan ketahanan negara, ekonomi, sosial, budaya, dan lingkungan. Untuk melakukan penataan ruang wilayah di kawasan ini diperlukan data dan informasi yang akurat, sehingga dapat dijadikan acuan dalam penatan dan pelaksanaan kegiatan transportasi laut di wilayah tersebut. Beberapa data dan informasi yang diperlukan yaitu tentang kondisi meteorologi terutama angin, data hidrooseanografi berupa arus, gelombang dan pasang surut.

Informasi angin dan gelombang laut sangat penting untuk berbagai aktivitas di dalam dan di luar pantai seperti konstruksi pesisir, navigasi kapal, dan pengembangan sumber daya kelautan (misalnya, industri pertambangan dan minyak) (Huang et al., 2017). Informasi kondisi angin dan gelombang sangat penting untuk mendukung keselamatan pelayaran maritim (Galic et al., 2014). Kecepatan angin yang terukur akurat dapat dimanfaatkan sebagai sumber energi terbarukan secara mandiri, dan digunakan secara lokal di pedesaan dan daerah terpencil (Ahmed et al., 2006). Menurut Thomas dan Dwarakishb (2015), gelombang yang disebabkan oleh angin adalah bagian penting di daerah pantai dan laut. Gelombang merupakan variabel proses yang dominan dalam mengendalikan perubahan bentuk dan evolusi pesisir (Arnot, 2010).

Arus permukaan di laut terbuka, merupakan faktor penting untuk aplikasi praktis, seperti peramalan iklim, pengawasan lingkungan laut, navigasi kapal, dan lain-lain (Chen et al., 2015). Kapal akan memanfaatkan arus laut saat mereka berada di sepanjang rute yang direncanakan, dan untuk menghindari arus saat mereka berada dalam arah berlawanan (Chang et al., 2013). Penggunaan arus laut yang menguntungkan bisa berdampak pada konsumsi bahan bakar yang lebih rendah dan mengurangi waktu transit (International Maritime Organization, 2011). Pasang surut dibutuhkan dalam menentukan keselamatan penggunaan alur pelayaran terutama alur keluar masuk dermaga. Fluktuasi pasang surut sangat penting di semua aspek zona pesisir dan mempengaruhi proses fisik seperti tingkat aksi gelombang dan pengaliran air di muara, laguna dan teluk; aktivitas biologis seperti zonasi vegetasi (Arnot, 2010). Perbedaan antara elevasi pasang tinggi dan rendah adalah kisaran pasang surut dan mengontrol perjalanan tingkat air di garis pantai. Kisaran pasang surut rata-rata pada pasang surut air laut dapat digunakan sebagai deskriptor pantai yang penting.

Penelitian mengenai parameter meteorologi dan oseanografi ini dilakukan untuk mendapatkan data yang dapat menginformasikan kondisi meteo-oseanografi. Informasi ini sangat dibutuhkan dalam kegiatan transportasi laut di wilayah Selat Lirang.

\section{Bahan dan Metode}

\section{Bahan}

Bahan yang digunakan berupa data parameter meteorologi dan hidrooseanografi, yaitu data pengukuran angin, gelombang, arus dan pasang surut. Pengambilan data tersebut dilakukan di perairan Selat Lirang Kabupaten Maluku Barat Daya.

\section{Metode}

Metode penelitian yang digunakan adalah metode observasi. Data angin diukur dengan menggunakan Anemometer, sedangkan data 
arus menggunakan Acoustic Doppler Current Profiller (ADCP) merk Nortex AS Aquadop Profiller frekuensi $600 \mathrm{kHz}$. Data gelombang diukur dengan Wave Recorder yang terintegrasi dengan ADCP, dengan jangka waktu pencatatan data setiap 30 menit selama 5 hari pada 15-19 April 2016 pada koordinat $08^{\circ} 00^{\prime} 57,2^{\prime \prime}$ LS dan $125^{\circ} 46^{\prime} 17,8^{\prime \prime}$ BT dengan kedalaman 8 meter (Gambar 1). Pengukuran data gelombang lapangan dilakukan untuk mendapatkan parameter gelombang seperti tinggi gelombang $(\mathrm{H})$ dan periode gelombang (T). Data gelombang yang diperoleh dari hasil pengukuran kemudian dianalisis dengan menggunakan penentuan gelombang representatif. Data pasang surut diukur dengan Hobo Water Level Logger (tipe U20-001-01) selama 15 hari x 24 jam. Semua data yang diperoleh dianalisa dengan pendekatan metode kuantitatif.

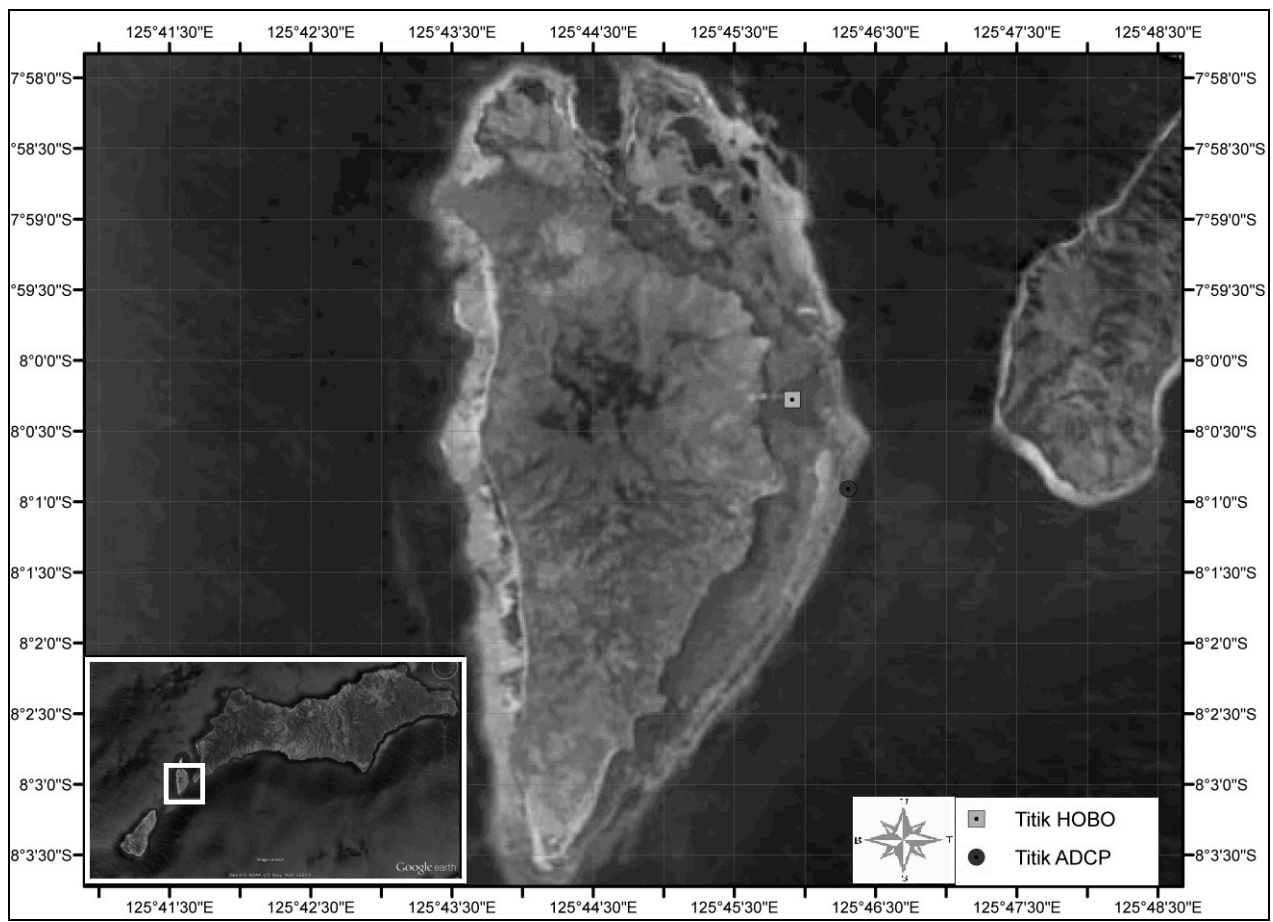

Gambar 1. Peta Lokasi Penelitian

Figure 1. Map of Research Location

Analisis data angin pada penelitian ini untuk melihat kecepatan dan arah dominan angin dengan memasukkan ke dalam mawar angin. Data arus hasil pengukuran di lapangan menggunakan ADCP stasioner (Gambar 1) yang di tempatkan di satu titik selama 5 x 24 jam untuk mendapatkan nilai kecepatan dan arah arus. Kecepatan arus ini diuraikan komponennya menjadi komponen zonal (Timur-Barat) dan meridional (Utara-Selatan). Hasil perhitungan komponen $\mathrm{U}$ dan $\mathrm{V}$ ini disajikan dalam bentuk grafik dan dianalisis untuk menggambarkan pola arus dan arus dominan yang terjadi di tempat penelitian.
Nilai kecepatan arus juga diolah di Matlab dengan prediksi T-Tide untuk mengetahui hubungan arus total yang terukur dengan arus yang ditimbulkan oleh pasang surut dan arus residu. Analisis kedekatan arus pengukuran dengan arus residu maupun arus pasang surut menggunakan analisis Root Mean Square Error (RMSE) (James et al., 2013). Dari pengukuran pasang surut dilapangan, pengolahan data dengan menggunakan metoda Admiralty untuk mendapatkan komponen harmonik pasang surut dan nilai-nilai elevasi penting. 


\section{Hasil dan Pembahasan}

Pola Angin memberikan gambaran frekuensi dan presentase kecepatan angin di wilayah Selat Lirang yang disajikan pada Gambar 2.

Berdasarkan hasil observasi didapatkan data hasil analisis mawar angin (Windrose) yang

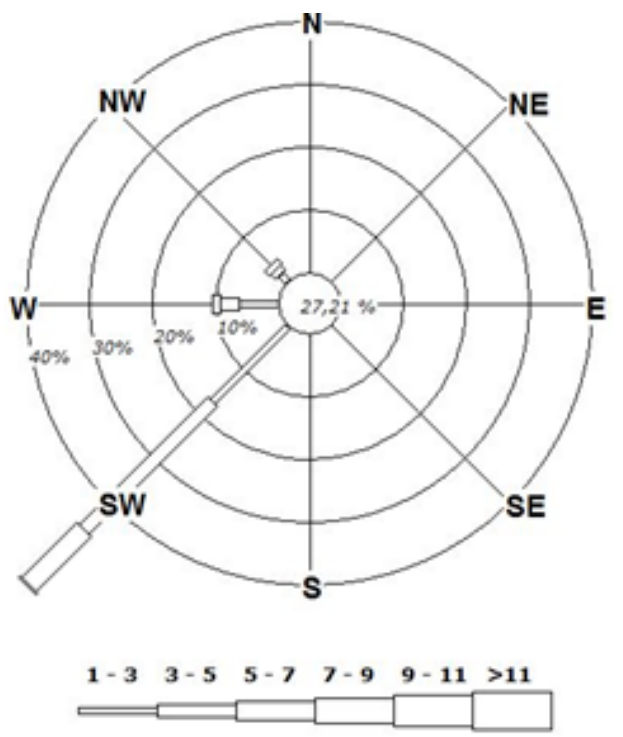

Gambar 2. Wind Rose Hasil Pengukuran selama Tanggal 15-19 April 2016. Frekuensi Kejadian Angin dalam Satuan Persen dan Kecepatan Angin dalam Satuan m/detik

Figure 2. Wind Rose of Measurements Result During April 15-19, 2016. The Frequency of Wind Events in Percent Units and Wind Speed in $\mathrm{m} / \mathrm{sec}$ Units

Hasil pengukuran menunjukkan bahwa pergerakan arah angin berasal dari baratdaya sampai barat laut dimana arah baratdaya mendominasi sebesar $58.44 \%$, yang mengindikasikan angin musim barat masih mendominasi daerah penelitian. Dominasi arah angin dari baratdaya erat kaitannya dengan angin baratan yang berhubungan dengan pembelokan angin yang terjadi di wilayah Indonesia. Hal ini seperti yang disampaikan oleh Mulyana (2002), pada bulan April yang merupakan peralihan monsun Asia ke monsun Australia, angin baratan yang bertiup di atas wilayah Papua termasuk wilayah penelitian merupakan bagian dari pembelokkan angin ke arah selatan yang berasal dari Pasifik sebelah timur Filipina ketika memasuki wilayah Sulawesi utara.

Variasi kecepatan dari arah baratdaya, persentasenya tersebar merata dalam rentang kecepatan yang berbeda pada masing masing kelas dengan kecepatan berkisar 3-5 m/detik sebesar $28.83 \%$, kecepatan 5-7 m/detik sebesar $12.29 \%$ dan kecepatan $1-3 \mathrm{~m} /$ detik sebesar
16.98\%. Sementara itu persentase kecepatan terbesar pada kisaran 7-9 m/s hanya memiliki sebesar $0.34 \%$. Kecepatan angin dari arah baratdaya yang berkisar 3-5 m/detik mendominasi sebesar 29\%. Dari arah yang lainnya, persentase kecepatan dari arah barat mencapai $10.45 \%$, sedangkan dari baratlaut hanya mencapai $3.91 \%$.

Karakteristik angin pada bulan April sebagai representasi musim peralihan I, dimana variasi arah angin yang umumnya bergeser dari baratlaut, utara sampai dengan tenggara seperti yang disampaikan oleh Fadika $d k k$. (2014) belum terlihat pada saat pengukuran. Berdasarkan posisi geografis perairan Selat Lirang, yang terbuka terhadap angin dari baratdaya (Gambar 1), memungkinkan arah angin dari baratdaya sampai baratlaut ini dapat berpengaruh terhadap dinamika perairan Selat Lirang. Angin dari arah baratdaya berpotensi menggerakkan arus permukaan yang arahnya menyebar sepanjang perairan Selat Lirang. Angin yang berhembus di atas permukaan laut 
menimbulkan tegangan pada permukaan laut, di mana semakin lama angin bertiup, semakin besar pula energi yang dapat membangkitkan arus (Dawe dan Thompson, 2006; Tamura et al., 2008).

\section{Karakter Arus}

Hasil pengukuran arus total yang dianalisis dalam arah zonal dan meridional, menunjukkan bahwa kecepatan arus meridional maksimal terukur pada kedalaman $1.5 \mathrm{~m}$ yang mencapai $1.174 \mathrm{~m} /$ detik (Gambar 3a). Arah arus maksimal terukur menuju ke tenggara. Sedangkan pada arah zonal, arus maksimal mencapai $0.981 \mathrm{~m} /$ detik (Gambar $3 b)$, yang mengarah ke timur pada kedalaman $6.5 \mathrm{~m}$. Pergerakan arus pada kedua kedalaman kemungkinan berkaitan erat dengan pembangkitan oleh angin baratan yang bertiup dari baratdaya sampai dengan baratlaut, dimana potensi transfer energi dari angin seiring durasi waktu angin bertiup (Dawe dan Thompson, 2006; Tamura et al., 2008).
Untuk melihat peranan faktor lain selain angin dalam pembangkitan arus total pengukuran, dilakukan analisis deskriptif terhadap pola pasang surut yang terukur. Kecepatan arus maksimal arah meridional terjadi pada kondisi perairan menuju pasang (Gambar 3a), sedangkan dalam arah zonal kecepatan maksimal terukur pada saat surut (Gambar 3b). Arus meridional pada kedalaman $1.5 \mathrm{~m}$ menunjukkan adanya peranan perubahan elevasi pasang surut dalam menentukan kecepatan arus. Hal ini menunjukkan adanya peranan angin bersamaan dengan pergerakan pasang surut dalam menggerakkan arus di kedalaman ini. Kecepatan arus maksimal pada kondisi menuju pasang ini seperti yang disampaikan oleh Ross (1995), bahwa arus pasang dan arus surut yang paling kuat biasanya terjadi sebelum atau mendekati waktu pasang tinggi dan rendah, sedangkan arus terlemah pada kondisi slack tide. Berdasarkan penjelasan ini, maka kecepatan maksimal pada kedalaman $6.5 \mathrm{~m}$ tidak berhubungan dengan pembangkitan pasang surut.

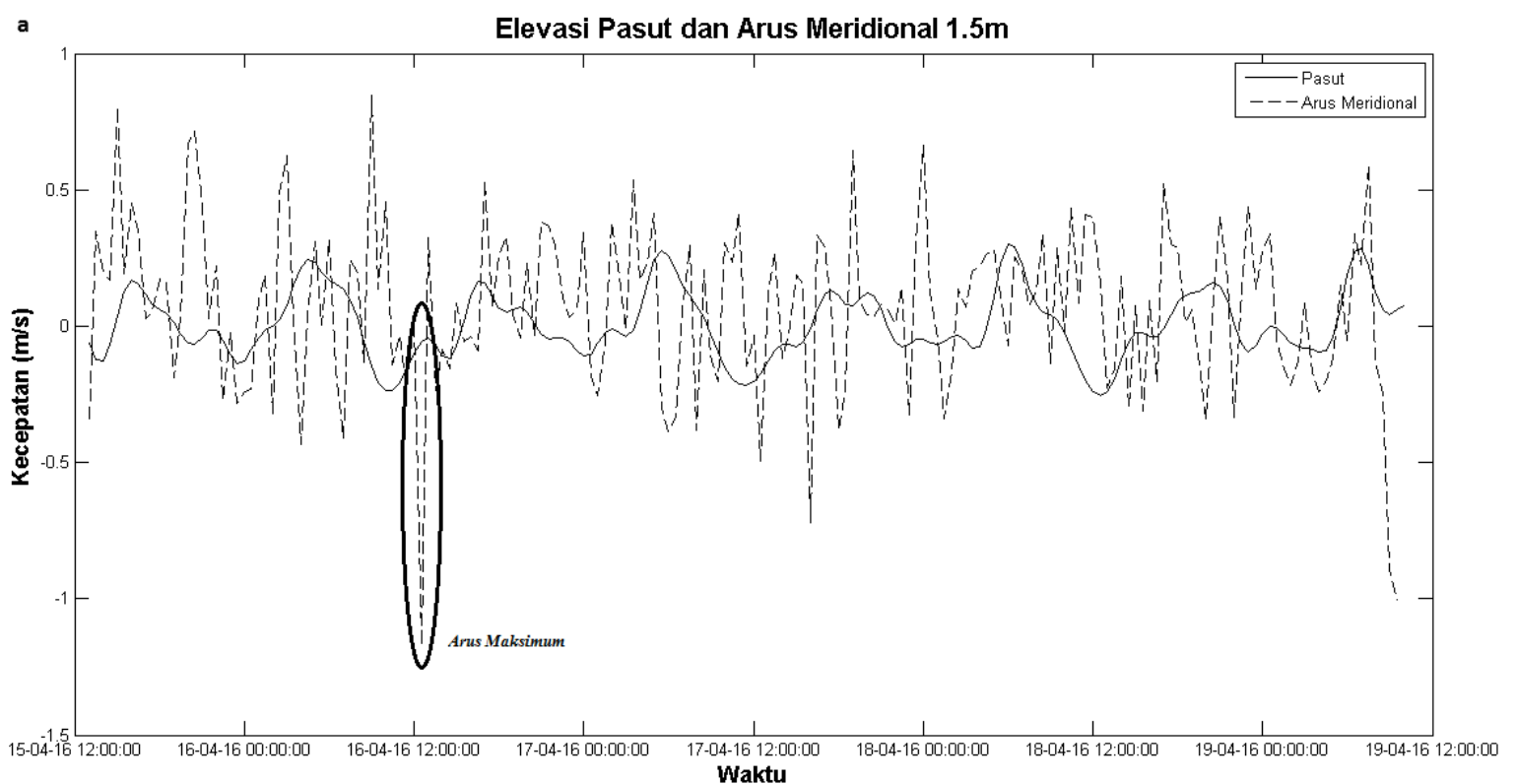


b

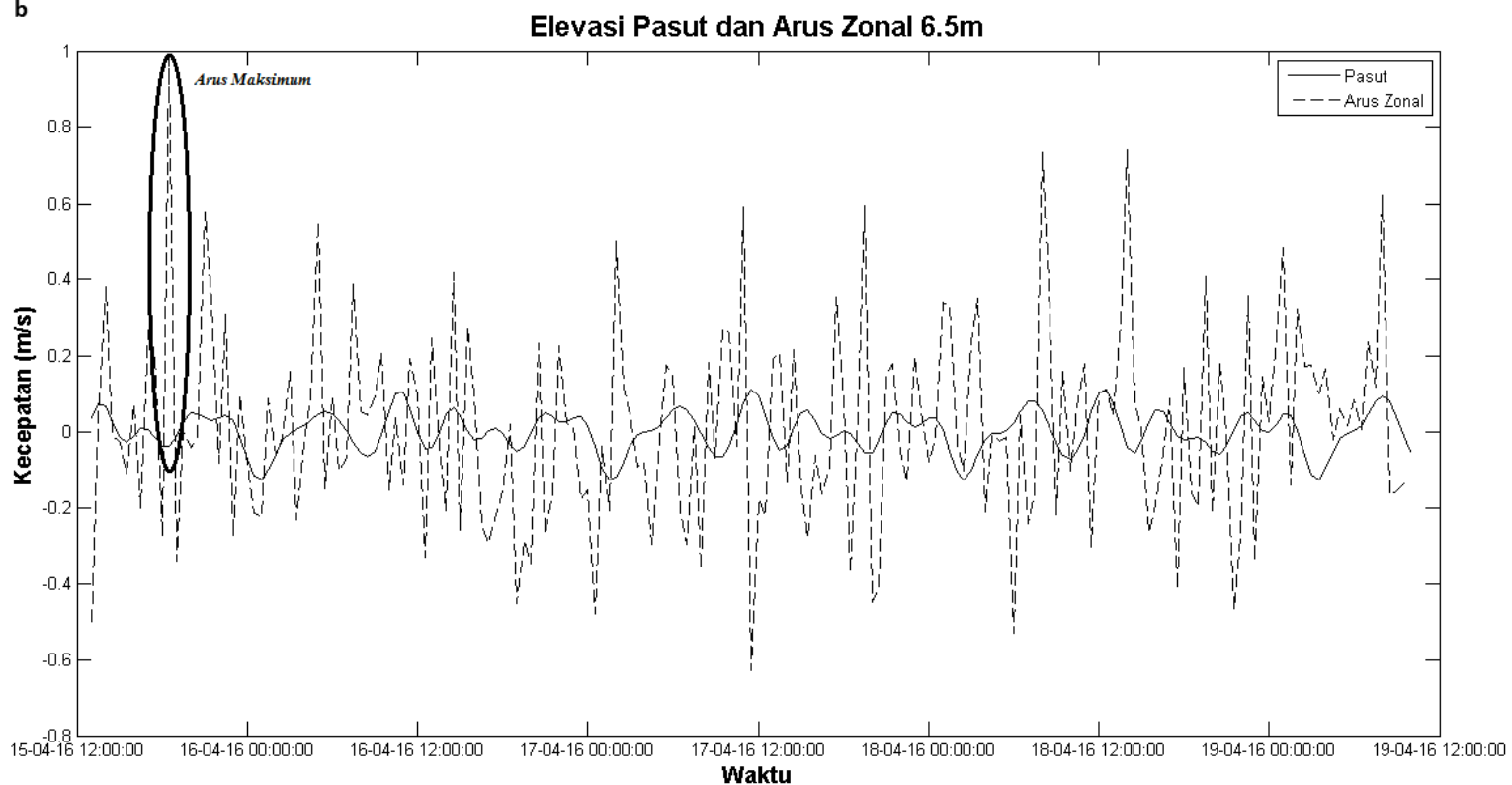

Gambar 3. Elevasi Pasut dan Arus Maksimum. a) Arus Meridional 1.5m; b) Arus Zonal $6.5 \mathrm{~m}$ Figure 3. Elevation of Tides and Maximum Current. a) Meridional Stream in 1.5m; b) The Zonal Current in $6.5 \mathrm{~m}$

Sementara itu, hasil pengukuran arus stasioner didapatkan pola arus pada masing masing kedalaman yang dibandingkan dengan data arah dan kecepatan angin yang tersaji pada gambar (Gambar 4). Kedalaman arus dianalisis dari $1.5 \mathrm{~m}$ sampai dengan $7.5 \mathrm{~m}$ dengan arah meridional dominan menuju utara. Sedangkan dalam arah zonal, arah arus dominan bergerak ke arah Timur laut. Berdasarkan pola arus dari masing masing kedalaman $1.5 \mathrm{~m}$ sampai dengan $7.5 \mathrm{~m}$, baik secara meridional dan zonal dimungkinkan angin memberikan pengaruh terhadap pergerakan arus dengan arah angin dominan berasal dari baratdaya.

Angin dari arah baratdaya menggerakkan arus ke arah utara dan timurlaut, sedangkan angin dari barat menggerakkan arus ke arah timur sampai dengan tenggara. Angin dari baratlaut menimbulkan arus ke timur sampai dengan selatan. Arah angin dari baratdaya yang dominan, berhubungan dengan banyaknya arus yang mengarah ke utara sampai dengan timurlaut. Hal ini menunjukkan keterbukaan perairan Selat Lirang terhadap pergerakan angin tersebut. Hubungan arah angin dengan arus yang terbentuk pada hasil analisis dalam penelitian ini mendukung pernyataan dari Mao dan Heron (2008) yang menyatakan bahwa variasi angin berperan dalam pembangkitan arus permukaan. Variasi arus permukaan juga berhubungan langsung dengan variasi angin musiman (Zhao et al., 2011; Solabarrieta et al., 2015). 


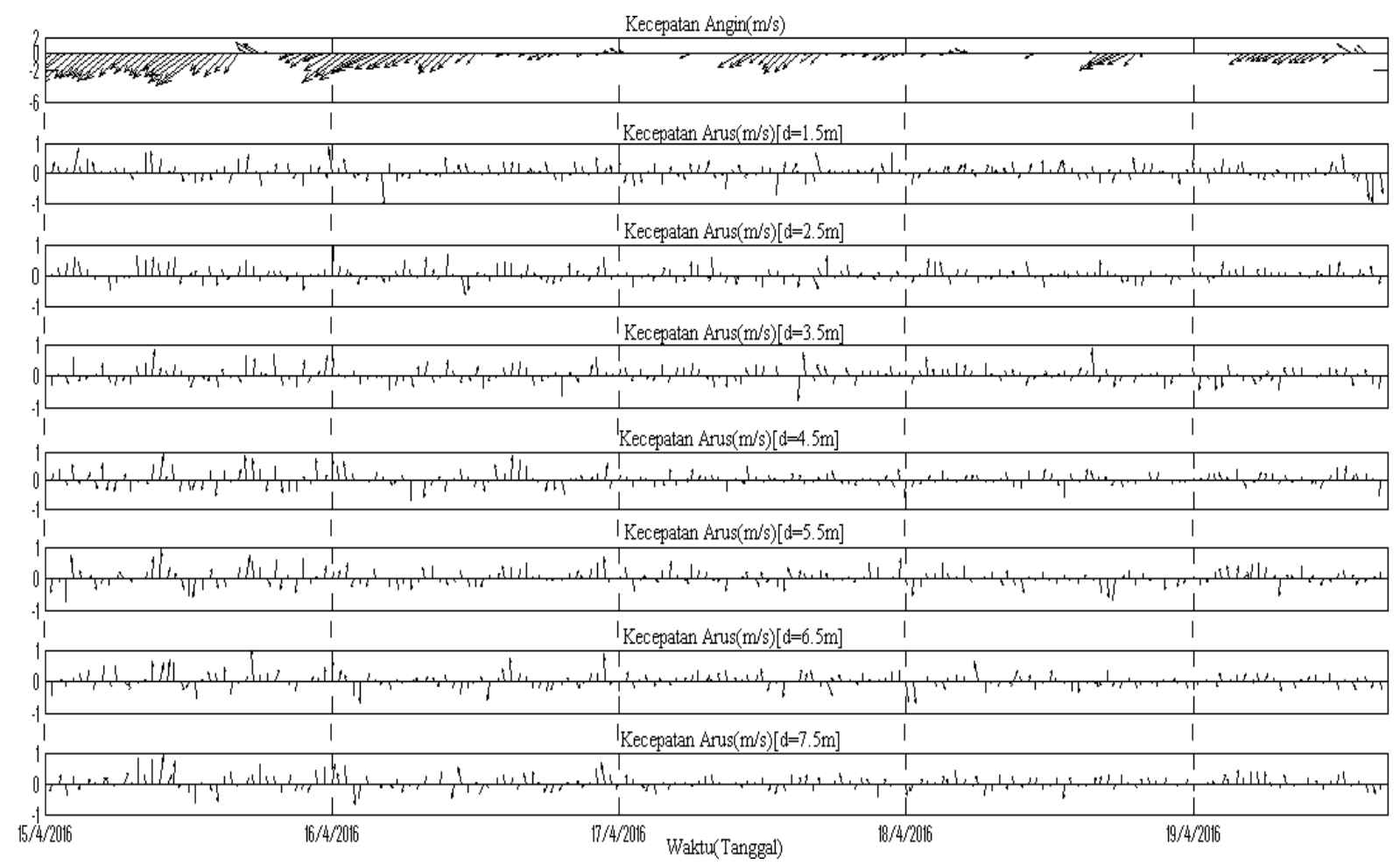

Gambar 4. Stick plot Arah Angin dan Arus Tanggal 15-19 April 2016 di Perairan Selat Lirang Angin dan Arus Diukur pada Stasiun Tetap (stationer).

Figure 4. Stick Plot of Wind Direction and Current, April 15-19, 2016 in Lirang Strait Waters. Wind and Current Measured at Station Fixed (Stationer).

\section{Karakteristik Gelombang}

Hasil pengukuran gelombang secara umum menunjukan nilai yang relatif kecil (Tabel 1). Hal ini terjadi karena pada saat pengukuran data lapangan dilakukan pada pertengahan bulan April yang termasuk kedalam musim peralihan I. Sesuai dengan pernyataan Kurniawan dkk. (2011), bahwa kondisi kecepatan angin rendah di atas perairan Indonesia pada musim peralihan sehingga gelombang laut lebih rendah. Selain itu, pada musim peralihan I ini perairan Selat Lirang terlindung dari gelombang oleh Pulau Lirang di sisi barat dan Pulau Wetar di utara.
Ketinggian gelombang maksimal signifikan (Hs) selama pengukuran mencapai tertinggi $0.276 \mathrm{~m}$ dengan periode 3.5 detik. Nilai Hs ini menunjukkan ketinggian gelombang yang signifikan terukur selama periode observasi sebesar 33\% dari total gelombang pengukuran. Hs terukur masih jauh dibawah nilai ketinggian gelombang yang umum membahayakan bagi keselamatan kapal, yaitu di atas 3m (Zhang dan Ming Li, 2017). Untuk itu kondisi ketinggian gelombang pada musim peralihan ini cenderung tidak membahayakan bagi aktifitas bongkar muat dari kapal kecil ke kapal besar di timur perairan Selat Lirang.

Tabel 1. Tinggi (H) dan Periode (T) Gelombang Harian Pengukuran Tanggal 15-19 April 2016.

Table 1. High (H) and Period (T) Daily Wave Measurements, April 15-19, 2016.

\begin{tabular}{ccccccc}
\hline Tanggal & $\begin{array}{c}\text { Hmax } \\
(\mathrm{m})\end{array}$ & Hs $(\mathrm{m})$ & $\begin{array}{c}\text { Hmin } \\
(\mathrm{m})\end{array}$ & $\begin{array}{c}\text { Tmax } \\
(\mathrm{dt})\end{array}$ & Ts $(\mathrm{dt})$ & Tmin $(\mathrm{dt})$ \\
\hline 15 April 2016 & 0.46 & 0.108 & 0.07 & 3.94 & 3.695 & 3.28 \\
16 April 2016 & 0.45 & 0.276 & 0.09 & 4.93 & 3.553 & 3.26 \\
17 April 2016 & 0.46 & 0.172 & 0.07 & 4.29 & 3.618 & 3.23 \\
18 April 2016 & 0.14 & 0.085 & 0.06 & 4.43 & 3.922 & 3.33 \\
19 April 2016 & 0.12 & 0.1 & 0.06 & 3.92 & 3.6 & 3.33 \\
\hline
\end{tabular}


Berdasarkan gaya pembangkit gelombang yang terbentuk pada lokasi penelitian dikategorikan sebagai gelombang yang dibangkitkan oleh angin karena memiliki periode gelombang berkisar 3.23 - 4.93 detik, yang artinya gelombang berperiode pendek (Holthuijsen, 2007). Hal ini menunjukkan bahwa gelombang yang terbentuk di Perairan Selat Lirang, dinamikanya mengikuti fluktuasi kejadian angin lokal yang cenderung kecil pada waktu pengambilan data di bulan April. Ketinggian gelombang akibat angin lokal ini akan mengikuti laju perubahan energi gelombang yang ditransfer (Tamura et al., 2009).

Secara umum, hasil yang diperoleh dari data pengukuran lapangan belum dapat menggambarkan kondisi gelombang secara keseluruhan berdasarkan kondisi musim. Hal ini disebabkan oleh pengaruh musim dan angin yang bertiup pada saat pengukuran yang dilakukan hanya beberapa hari dalam satu musim, yaitu musim peralihan I. Pendekatan yang dapat dilakukan adalah dengan melakukan peramalan gelombang angin dalam jangka waktu tertentu.

\section{Pasang Surut}

Pengamatan pasang surut dilakukan selama 15 hari, dimulai dari tanggal 15 April 2016 hingga 30 April 2016. Pengolahan data pasang surut bulan April 2016 menggunakan metode Admiralty dan menghasilkan komponen harmonik pasang surut berupa M2. S2. K2. N2. K1. O1. P1 dan Q1 (Tabel 2). Berdasarkan perhitungan dengan menggunakan nilai - nilai komponen harmonik tersebut didapatkan nilai elevasi penting (Tabel 3).

Tabel 2. Hasil Perhitungan Nilai Konstanta Harmonik Pasang Surut Perairan Selat Lirang.

Table 2. Calculation Result of Tidal Harmonic Constants of Lirang Strait Waters.

\begin{tabular}{ccc}
\hline Konstanta Harmonik & Amplitudo $(\mathrm{cm})$ & Beda Fase $\left(\mathrm{g}^{\circ}\right)$ \\
\hline S0 & 89.68 & \\
M2 & 31.77 & 91.68 \\
S2 & 22.71 & 112.79 \\
N2 & 5.16 & 294.30 \\
K1 & 26.23 & 131.86 \\
O1 & 8.70 & 109.89 \\
M4 & 0.66 & 242.18 \\
MS4 & 2.55 & 72.10 \\
K2 & 6.13 & 112.79 \\
P1 & 8.66 & 131.86 \\
\hline
\end{tabular}

Tabel 3. Nilai Elevasi Penting Data Pasang Surut Perairan Selat Lirang.

Table 3. Important Elevation Values of Tidal Data of Lirang Strait.

\begin{tabular}{cc}
\hline Keterangan & Elevasi $(\mathrm{cm})$ \\
\hline Z0 & 72.730 \\
MSL & 89.68 \\
HHWL & 193.87 \\
LLWL & -22.89 \\
F & 0.641 \\
LWL & 0.004 \\
HWL & 153.208 \\
MHWL & 127.206 \\
MLWL & 18.253 \\
\hline
\end{tabular}

Bilangan Formzahl yang diperoleh dari hasil analisa komponen harmonik pasang surut sebesar 0.641 yang menunjukan bahwa tipe pasang surut di perairan Pulau Lirang. Kabupaten Maluku Barat Daya adalah bertipe campuran condong harian ganda (Mixed Tide
Prevailing Semidiurnal). Tipe pasut campuran condong ke harian ganda ditandai dengan dalam satu hari terjadi dua kali air pasang dan dua kali air surut, tetapi tinggi dan periodenya berbeda (Poerbandono dan Djunarsjah. 2005). 
Nilai-nilai elevasi penting sangat bermanfaat dalam memandu aktifitas lalu lintas kapal, terutama terhadap alur keluar masuk pelabuhan. Nilai MHWL berperan dalam menentukan nilai elevasi dermaga. Untuk menentukan kedalaman dermaga diperlukan perhitungan lebih lanjut dengan menggunakan acuan dari ukuran kapal terbesar yang akan menggunakan dermaga dan nilai draft kapal. Nilai-nilai elevasi yang diperoleh ini dapat dijadikan acuan perhitungan lebih lanjut dalam pengelolaan dermaga Pulau
Lirang yang saat ini tidak berfungsi secara maksimal.

\section{Hubungan Arus Total Pengukuran, Arus Pasang Surut dan Arus Residu}

Analisis hubungan arus pengukuran terhadap arus pasang surut dan arus residu secara meridional dan zonal yang dilakukan pada kedalaman $1.5 \mathrm{~m}$ dan $7.5 \mathrm{~m}$ dengan tujuan untuk melihat perbedaan arus pada lapisan permukaan dan lapisan dalam yang tersaji pada Gambar 5 dan Gambar 6.
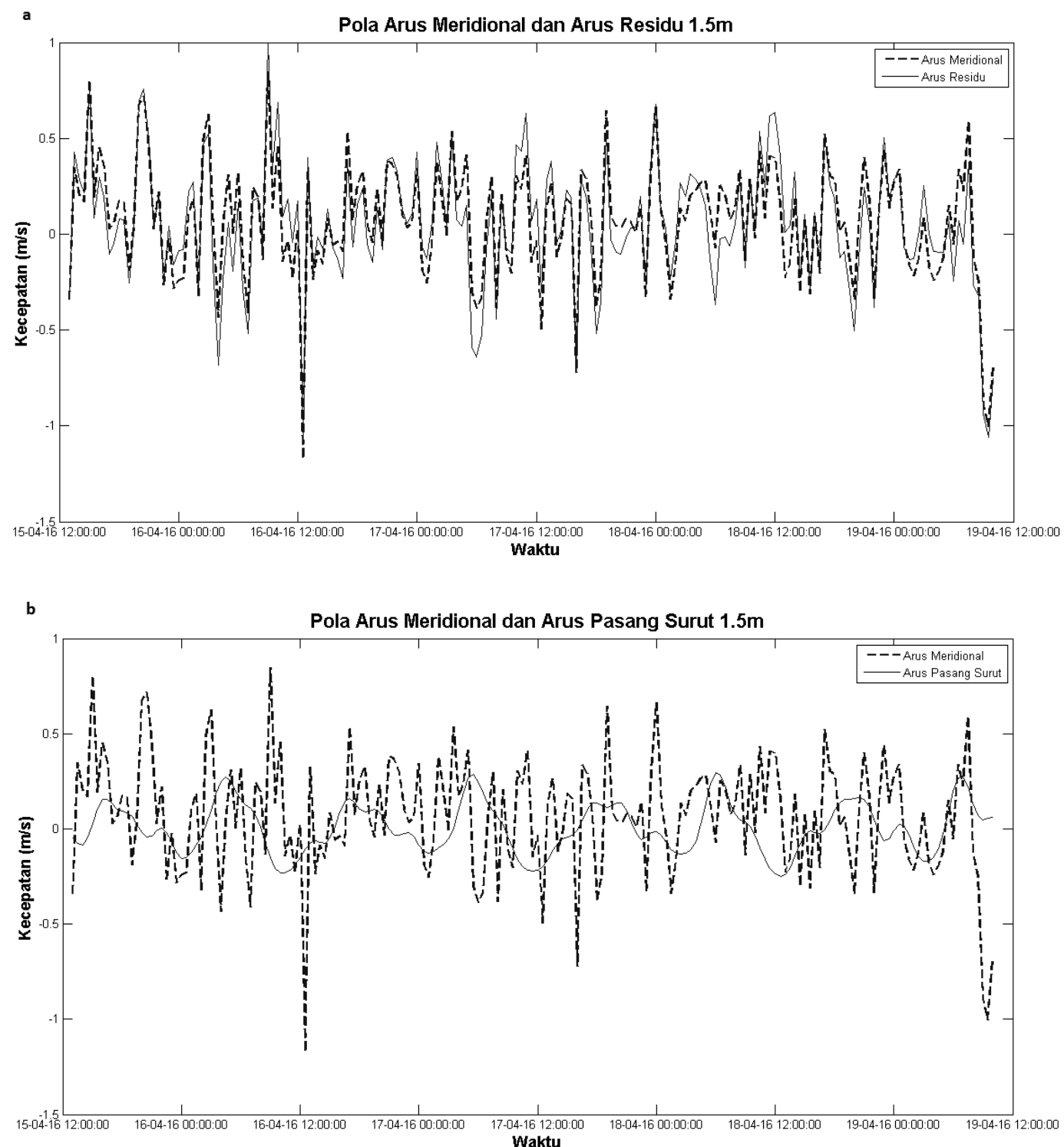

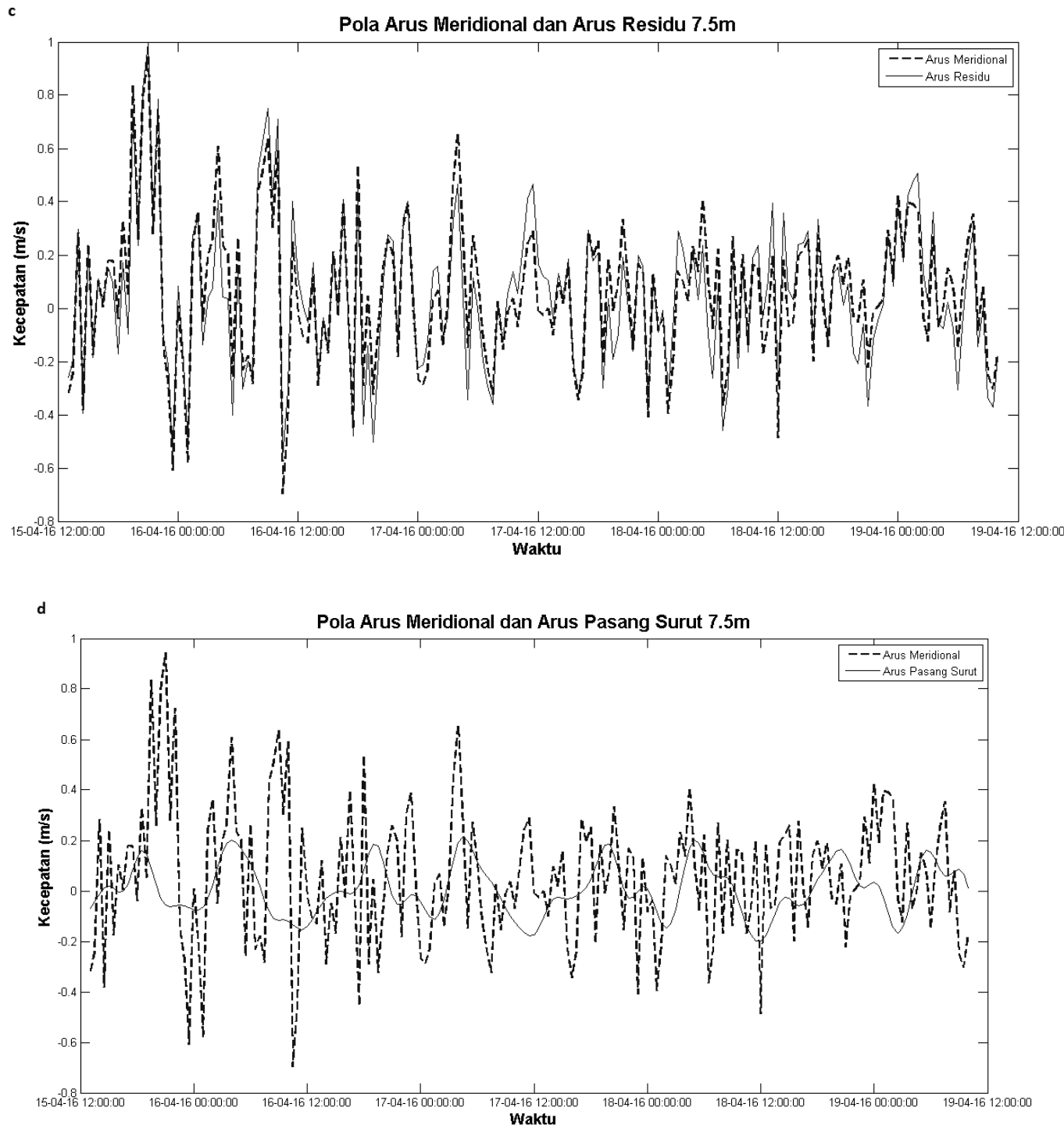

Gambar 5. Pola Arus Meridional. a) Arus pengukuran dan arus residu 1.5m. b) Arus pengukuran dan arus pasang surut $1.5 \mathrm{~m} . c$ ) Arus pengukuran dan arus residu $7.5 \mathrm{~m} . b$ ) Arus pengukuran dan arus pasang surut $7.5 \mathrm{~m}$.

Figure 5. Meridional Current. a) Measurement Current and Residual current at $1.5 \mathrm{~m}$. b) Measurement Current and Tidal Current at $1.5 \mathrm{~m}$. c) Measurement Current and Residual Current at $7.5 \mathrm{~m}$. b) Measurement Current and Tidal Current at $7.5 \mathrm{~m}$.

Pola arus meridional pada kedalaman $1.5 \mathrm{~m}$ maupun 7.5m (Gambar 5), menunjukkan kecepatan arus total pengukuran terlihat paling mendekati besarnya kecepatan arus residu. Hasil perhitungan RMSE pada kedalaman 1.5 $\mathrm{m}$, perhitungan arus total dengan arus residu memiliki nilai 0.0086 (Gambar 5a), arus total dengan arus pasang surut memiliki nilai 0.0184
(Gambar 5b). Sedangkan pada kedalaman $7.5 \mathrm{~m}$, arus total terhadap arus residu memiliki nilai 0.0105 (Gambar 5c), arus total dengan arus pasang surut memiliki nilai 0.0204 (Gambar 5d). Pola arus pada kedua kedalaman ini tidak jauh berbeda, yaitu arus total pengukuran lebih mendekati pola arus residu yang dibangkitkan oleh angin. 
Pola Arus Zonal dan Arus Residu 1.5m

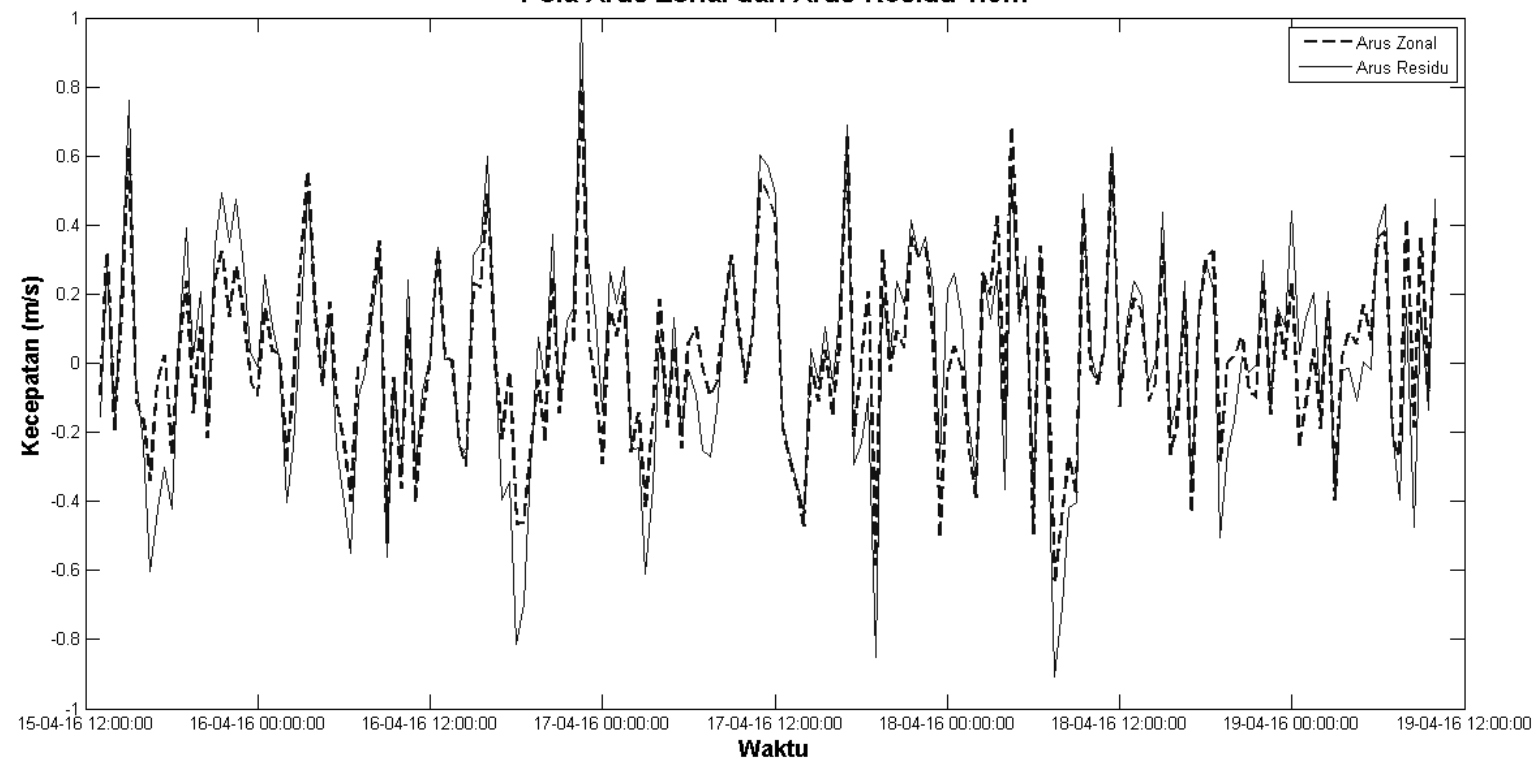

b

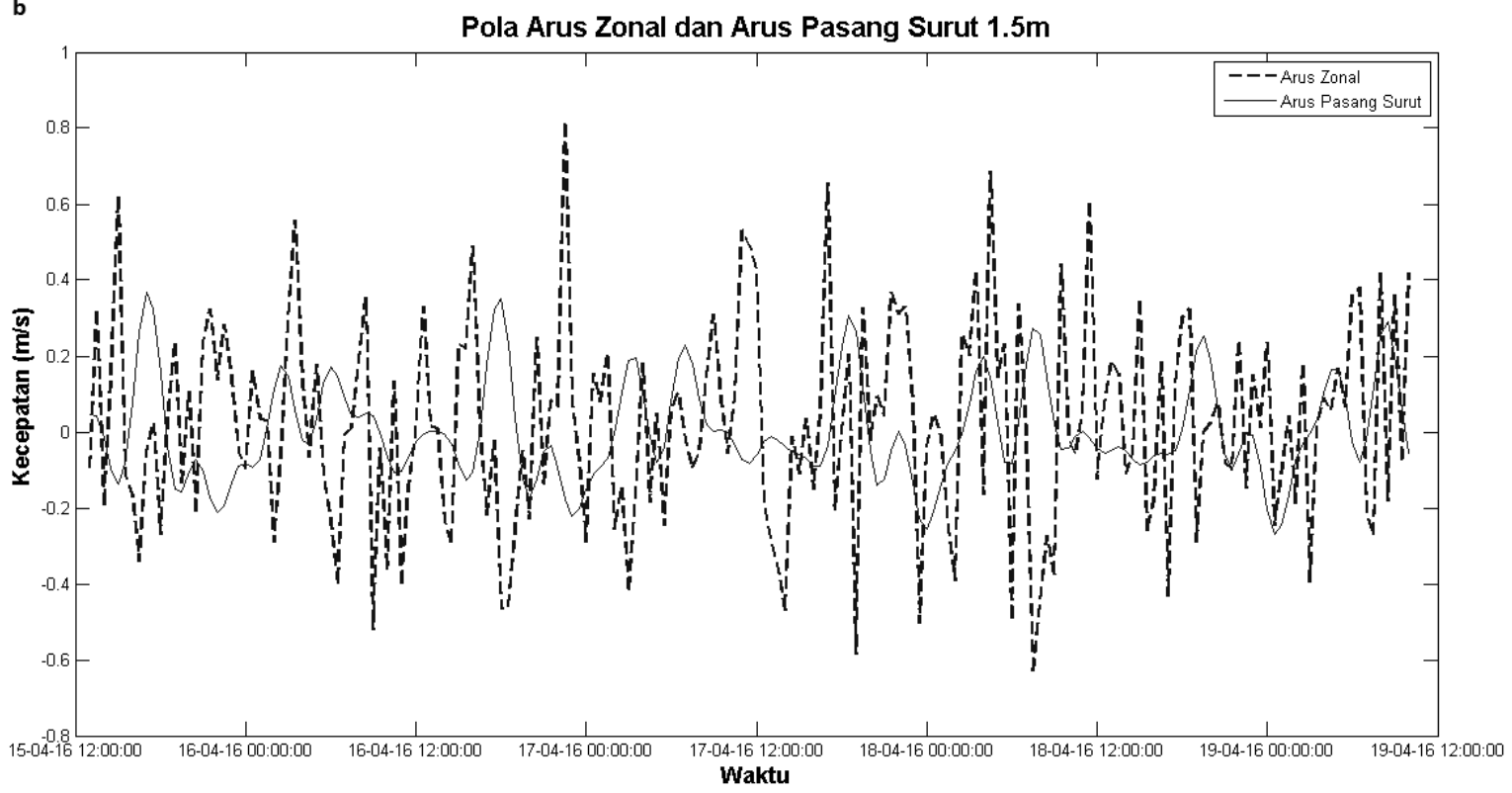



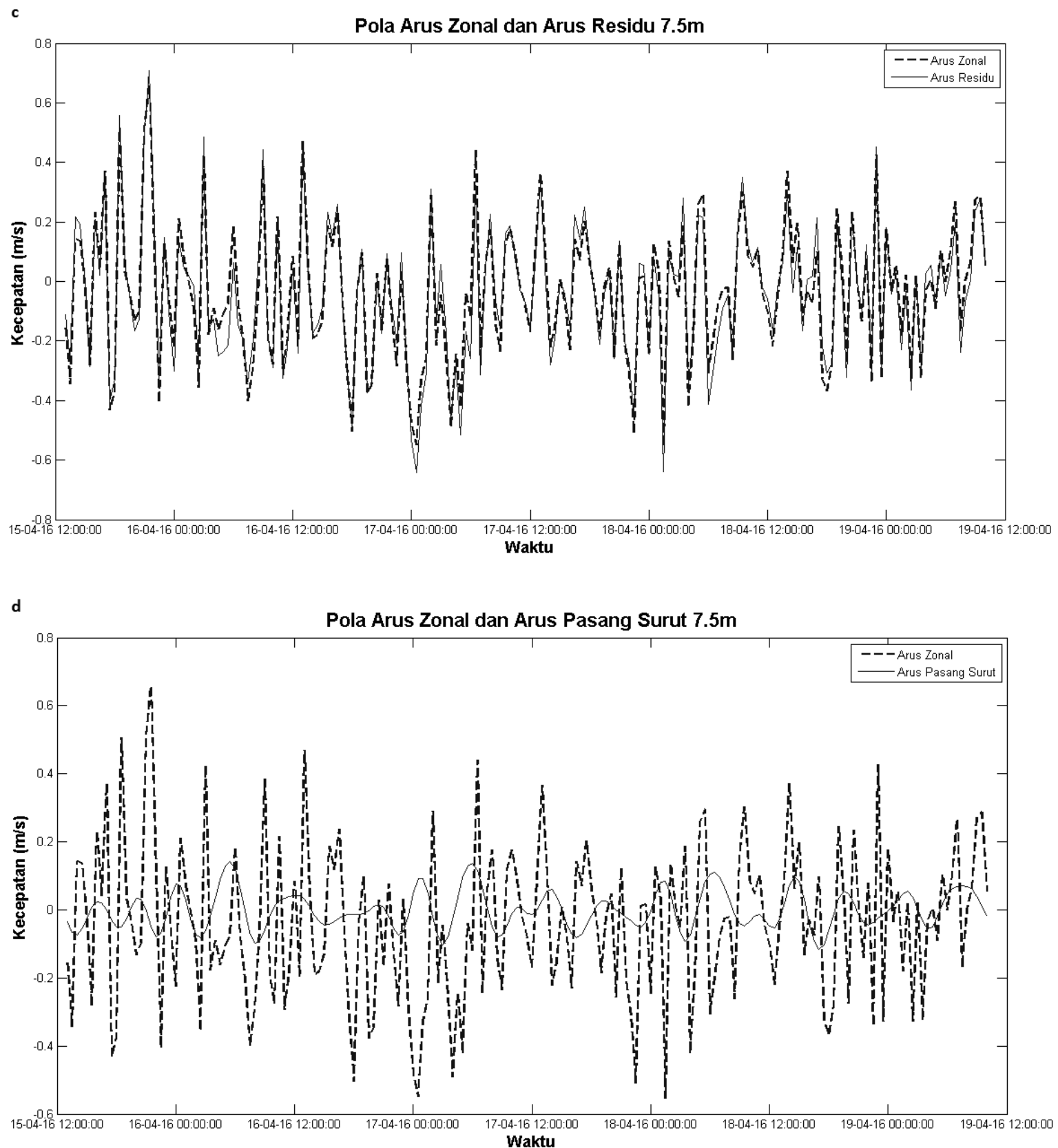

Gambar 6. Pola Arus Zonal. a) Arus Pengukuran dan Arus Residu 1.5m. $b$ ) Arus Pengukuran dan Arus Pasang Purut $1.5 \mathrm{~m} . c$ ) Arus Pengukuran dan Arus Residu 7.5m. b) Arus Pengukuran dan Arus Pasang Surut $7.5 \mathrm{~m}$.

Figure 6. Zonal Current. a) Measurement Current and Residual Current at $1.5 \mathrm{~m}$. b) Measurement Current and Tidal Current at $1.5 \mathrm{~m}$. c) Measurement Current and Residual Current at $7.5 \mathrm{~m} . \mathrm{b}$ ) Measurement Current and Tidal Current at $7.5 \mathrm{~m}$.

Dalam arah zonal, hubungan antara kecepatan arus pengukuran, arus residu dan arus pasang surut pada kedalaman $1.5 \mathrm{~m}$ dan $7.5 \mathrm{~m}$ ditunjukkan pada Gambar 6. Seperti halnya dalam arah meridional, arus zonal juga didominasi oleh arus residu. Arah angin dari baratlaut berperan dalam menggerakkan arus ke arah timur dan timur laut. Pola yang sama dari arus pengukuran dengan arus residu pada kedalaman 1.5m (Gambar 6a), dibuktikan dengan hasil perhitungan RMSE sebesar 0.0054 (Gambar 6a), lebih kecil dibandingkan perhitungan arus total pengukuran terhadap arus pasang surut (0.0162) (Gambar 6b). Sedangkan pada kedalaman $7.5 \mathrm{~m}$, nilai RMSE arus total terhadap arus pasut sebesar 0.0183 
(Gambar 6c) dan terhadap arus residu sebesar 0.0071 (Gambar 6d).

Nilai perhitungan RMSE yang semakin kecil, menunjukkan adanya kemiripan data arus total pengukuran terhadap arus residu, baik secara zonal maupun meridional (James et al., 2013). Arus residu tidak mengalir ke arah yang sama dan dengan kecepatan yang sama, tetapi berfluktuasi. Hal ini disebabkan oleh variasi arus yang membentuk arus residu di pesisir (Yanagi, 1980). Selain itu, bahwa komponen utama dari arus residu di perairan adalah arus residu yang diinduksi pasang, arus yang digerakkan oleh angin dan arus yang digerakkan oleh densitas (Yanagi, 1999).

\section{Simpulan}

Observasi parameter meteorologi dan hidrooseanografi di Selat Lirang memberikan gambaran dinamika perairan pada bulan April. Kondisi angin pada saat penelitian manunjukkan bahwa pengaruh musim barat masih mendominasi Selat Lirang di musim peralihan I. Hal ini dibuktikan oleh hasil pengukuran angin yang dominan dari arah baratdaya, barat dan baratlaut. Ketiga arah angin tersebut berperan dalam gerak arus zonal dan meridional, dimana kecepatan maksimalnya terjadi pada kondisi perairan menuju pasang. Kondisi ini menunjukkan adanya peranan angin bersamaan dengan pergerakan pasang surut terhadap pergerakan arus. Kemiripan arus pengukuran terhadap arus residu yang disebabkan oleh angin ditunjukkan dengan nilai RMSE yang lebih kecil dibandingkan terhadap arus pasang surut, baik arus zonal maupun merdional.

Kondisi gelombang pengukuran menunjukkan kondisinya relatif kecil, hal ini berhubungan dengan faktor pembangkitan angin lokal yang lemah pada musim peralihan I. Selain itu lokasi perairan Selat Lirang yang terlindung oleh Pulau Wetar di utara dan Pulau Lirang di barat, berpengaruh terhadap penjalaran gelombang dari perairan laut lepas. Kondisi gelombang pada musim peralihan I ini cenderung tidak membahayakan bagi aktifitas di perairan Selat Lirang. Karakteristik dinamika pasang surut yang menunjukkan terjadinya dua kali air pasang dan dua kali air surut,dengan tinggi dan periode yang berbeda dan mencirikan tipe campuran condong harian ganda.

\section{Ucapan Terimakasih}

Terima kasih disampaikan kepada Balai Riset dan Observasi Laut, Perancak Bali yang telah mendanai kegiatan ini melalui DIPA BPOL TA 2016 yang menjadi induk bagi kegiatan penelitian ini.

\section{Daftar Pustaka}

Ahmed MA; F Ahmad and MW Akhtar. 2006. Assessment of Wind Power Potential for Coastal Areas of Pakistan. Turk Journal Physic, 30. 127 - 135.

Arnott RD. 2010. Introduction to coastal processes and geomorphology. Cambridge University Press, New York. ISBN-13 978-0-511-69133-1

Chang YC; R Shan Tseng; G Yu Chen; PC Chu and Y Ting Shen. 2013. Ship Routing Utilizing Strong Ocean Currents. The Journal of Navigation, 66, 825-835. doi:10.1017/S0373463313000441

Chen C; S Shiotani and K Sasa. 2015. Effect of ocean currents on ship navigation in the East China Sea. Ocean Engineering $104 . \quad$ DOI 10.1016/j.oceaneng.2015.04.062.

Dawe JT and L Thompson. 2006. Effect of ocean surface currents on wind stress, heat flux and wind power input to the ocean. Geophysical Researchs Letter, 33. L09604. doi:10.1029/2006GL025784.

Fadika, U., Rifai, A, Rochaddi. 2014. Arah Dan Kecepatan Angin Musiman Serta Kaitannya Dengan Sebaran Suhu Permukaan Laut Di Selatan Pangandaran Jawa Barat. Jurnal Oseanografi. 3 (3) :429-237.

Galic S; Z Lusic and I Skoko. The Role And Importance Of Safety In Maritime Transportation. 6th International maritime science conference. April 28th-29th, 2014, Solin, Croatia.

Holthuijsen L. 2007. Wave in oceanic and coastal waters. Cambridge University Press, New York.

Huang W; X Liu and EW Gill. 2017. Ocean Wind and Wave Measurements Using X-Band Marine Radar: $A$ Comprehensive Review Remote Sens. 2017, 9, 1261; doi:10.3390/rs9121261 
lkilic C. 2012. Wind energy and assessment of wind energy potential in Turkey. Renewable and Sustainable Energy Reviews 16 (2012) 1165-1173. doi:10.1016/j.rser.2011.11.021.

International Maritime Organization. 2011. Assessment of IMO Mandated energy efficiency measures for international shipping, IMO-MEPC 63/INF.2, 31 October 2011.

James G; D Witten; T Hastie and R Tibshirani. 2013. An introduction to statistical learning (p. 68). New York: Springer.

Keputusan Presiden RI no 6 tahun 2017. Tentang penetapan pulau-pulau kecil terluar. Jakarta

Kurniawan R; MN Habibie dan Suratno. 2011. Variasi Bulanan Gelombang Laut Indonesia. Jurnal Meteorologi dan Geofisika, 12 (3): 221 - 232.

Luo Y; D Wang; TP Gamage; F Zhou; CM Widanage, and T Liu. 2018. Wind and wave dataset for Matara, Sri Lanka. Earth System. Science Data, 10, 131-138, 2018. https://doi.org/10.5194/essd-10-1312018.

Mao Y and ML Heron. 2008. The Influence of Fetch on the Response of Surface Currents to Wind Studied by HF Ocean Surface Radar. American Meteorological Society Vol 38. DOI: 10.1175/2007JPO3709.1

Mulyana, E. 2002. Analisis Angin Zonal di Indonesia selama Periode ENSO. Jurnal Sains dan Teknologi Modifikasi Cuaca, Vol. 3, No. 2, 2002, 115-120.

Norman, Y., Ihsan, N., Arsyad, M. 2012. Analisis Distribusi Arus Permukaan Laut Di Teluk Bone Pada Tahun 2006-2010. Jurnal Sains dan Pendidikan Fisika. 8 (3) : 288-295.

Peraturan Presiden Republik Indonesia Nomor 33 Tahun 2015. Rencana tata ruang kawasan perbatasan negara di provinsi Maluku. Jakarta.

Poerbandono E dan E Junarsjah. 2005. Survei hidrografi. Refika Aditama. Bandung.

Solabarrieta. L; A Rubio; M Cardenas; S Castanedo; G Esnaola; FJ Mendez; R Medina and L Ferrer. 2015.
Probabilistic relationships between wind and surface water circulation patterns in the SE Bay of Biscay. Ocean Dynamics 65(9-10). 12891303.

Ross, D.A. 1995. Introduction to oceanography. New York, NY: HarperCollins. pp. 236-242.

Tamura H; T Waseda and Y Miyazawa. 2008. Freakish Sea State and SwellWindsea Coupling: Numerical Study of The Suwa-Maru Incident. Geophysical Research Letter, 36, L01607,

https://doi.org/10.1029/2008GL0362 $\underline{80}$.

Thomas J and GS Dwarakishb. 2015. International Conference on Water Resources. Coastal and Ocean Engineering. Department Of Applied Mechanics And Hydraulics. Nitk Surathkal. Mangalore. Karnataka India Aquatic Procedia 4: 443 - 448.

Yanagi T. 1980. Physical oceanography in the Seto Inland Sea. Umi to Sora. 56,6776 (in Japanese with English caption).

Yanagi T. 1999. Residual flow. Coastal oceanography. Kluwer Academic Pub. 35-37

Zhao J; X Chen; W Hu; J Chen and M Guo. 2011. Dynamics of Surface Currents Over Qingdao Coastal Waters in August 2008. Journal of Geophysical Research: Ocean (1978-2012) 116 (C10).

Zhang $\mathrm{Z}$ and $\mathrm{X}$ Ming Li. Global Ship Accidents and Ocean Swell-Related Sea States. Natural Hazards Earth System Science, 17, 2041-2051, 2017 https://doi.org/10.5194/nhess-172041-2017. 